\title{
An Endopolygalacturonase from Sclerotinia sclerotiorum Induces Calcium-Mediated Signaling and Programmed Cell Death in Soybean Cells
}

\author{
Anna Zuppini, ${ }^{1}$ Lorella Navazio, ${ }^{1}$ Luca Sella, ${ }^{2}$ Carla Castiglioni, ${ }^{2}$ Francesco Favaron, ${ }^{2}$ and \\ Paola Mariani ${ }^{1}$ \\ ${ }^{1}$ Dipartimento di Biologia, Università di Padova, via U. Bassi 58/B, 35131 Padova, Italy; ${ }^{2}$ Dipartimento Te. S.A.F., Sez. \\ Patologia Vegetale, Università di Padova, Viale dell'Università 16, 35020 Legnaro, Padova, Italy
}

Submitted 21 January 2005. Accepted 5 April 2005.

\begin{abstract}
A basic endopolygalacturonase (PG) isoform, produced early by Sclerotinia sclerotiorum when infecting soybean seedlings, was used to examine the signaling role of the enzyme in aequorin-expressing soybean cells. A cytosolic $\mathrm{Ca}^{2+}$ elevation was induced, with a rapid increase (phase 1) and a very slow decrease (phase 2 ) of $\mathrm{Ca}^{2+}$ concentration, indicating the involvement of $\mathrm{Ca}^{2+}$ ions in PG signaling. Within $1 \mathrm{~h}$ of PG-cell contact a remarkable level of cell death was recorded, significantly higher than the control cell culture turnover. The observed morphological and biochemical changes were indicative of the activation of programmed cell death; in particular, cytochrome $c$ release in the cytoplasm and activation of both caspase 9-like and caspase 3-like proteases were found. When a polygalacturonase-inhibiting protein (PGIP) and the PG were simultaneously applied to cells, both the $\mathrm{Ca}^{2+}$ increase and cell death were annulled. The possible roles of prolonged sustained cytosolic $\mathrm{Ca}^{2+}$ concentrations in inducing cell death and of the PG-PGIP interaction in preventing PG signaling are discussed.
\end{abstract}

Additional keywords: fungal hydrolytic enzyme.

In plant-microbe interactions, the plant cell wall plays several roles, as a physical barrier to the pathogen infection, as a source of nutrients for the invaders, and as origin of signaling molecules. To overcome the plant cell wall, early during pathogenesis, most fungal pathogens secrete a wide array of cell wall-degrading enzymes with different substrate specificity, which facilitate the penetration of the pathogens into the host. The activity of pectin-degrading enzymes, in particular endopolygalacturonases (PGs) and endopectate lyases, is crucial for the colonization of plant tissues (Prade et al. 1999), and these enzymes can be determinants of pathogenicity or virulence (Willats et al. 2001). PGs hydrolyze internal $\alpha(1-4)$ glycosidic bonds in deesterified regions of the middle lamella and primary cell wall homogalacturonans and, when produced in relevant amounts, as by some necrotrophic fungi, determine

\section{A. Zuppini and L. Navazio contributed equally to this work.}

Corresponding authors: P. Mariani; E-mail: marianip@civ.bio.unipd.it; Telephone: +39.049.8276277; Fax: +39.049.8276280; and F. Favaron; Email: francesco.favaron@unipd.it; Telephone: +39.049.8272892; Fax: +39.049 .8272890 . the maceration of infected tissues. PGs are often encoded by multigene families and produced in several molecular forms with different specificity and regulation. This multiplicity can confer adaptative flexibility to pathogens when infecting different hosts or plant organs (De Lorenzo et al. 2001).

Biologically active mixtures of oligogalacturonides (OGs) with various degrees of polymerization (from 2 to about 20 galacturonic acid residues) are released from the cell wall pectins by PGs (Ridley et al. 2001). OGs participate as endogenous signal molecules in the dialogue between host and microbe, activating in plants a cascade of physiological events that are at least partially $\mathrm{Ca}^{2+}$-mediated (Navazio et al. 2002) and elicit defense responses (Coté and Hahn 1994).

Plants synthesize a class of proteins that specifically counteract the fungal PG activity. These polygalacturonase-inhibiting proteins (PGIPs) are located in the plant apoplast, in which, by complexing PGs, they reduce the homogalacturonan breakdown rate and the depolymerization of active OGs into shorter, inactive fragments (De Lorenzo and Ferrari 2002).

Sclerotinia sclerotiorum is a necrotrophic fungus causing soft rots in a number of host plants, and PG and oxalic acid, abundantly secreted by $S$. sclerotiorum in the host tissue, contribute to disease symptoms (Godoy et al. 1990; Marciano et al. 1983).

In this paper, we demonstrate that a basic PG isoform expressed early by $S$. sclerotiorum during soybean infection (Favaron and Marciano 1992; Favaron et al. 2004) induces, in aequorin-expressing soybean cells, a rapid and sustained cytosolic $\mathrm{Ca}^{2+}$ elevation that, in turn, leads to cell death exhibiting several hallmarks of programmed cell death (PCD). Both the $\mathrm{Ca}^{2+}$ increase and cell death induced by the PG are prevented by the simultaneous administration to cells of the PG-inhibitor PGIP, suggesting that PG and PGIP protein interaction alters the sensing of the fungal signaling molecule by the plant cells.

\section{RESULTS}

PG induces a sustained increase

of intracellular $\mathrm{Ca}^{2+}$ concentration in soybean cells.

The PG purified from $S$. sclerotiorum was tested for its potential ability to elicit a $\mathrm{Ca}^{2+}$ response in soybean suspension cell cultures stably expressing aequorin. At a 0.5 enzyme reducing unit (RU) per milliliter dose, after a delay of $40 \mathrm{~s}$, a rapid increase in cytosolic free- $\mathrm{Ca}^{2+}$ concentration $\left(\left[\mathrm{Ca}^{2+}\right]_{\text {cyt }}\right.$ ) was observed, reaching a peak of about $1.2 \mu \mathrm{M} \mathrm{Ca}^{2+}$ after 
about 2 min (phase 1) and slowly decreasing to a concentration of $0.6 \mu \mathrm{M}$ within $10 \mathrm{~min}$ (phase 2) (Fig. 1). $\left[\mathrm{Ca}^{2+}\right]_{\mathrm{cyt}}$ remains at this value without declining to the basal level (approximately $100 \mathrm{nM}$ ) during the next hour (data not shown). The kinetic parameters of both phases of the $\mathrm{Ca}^{2+}$ transient were found to depend on the amount of PG applied (ranging from 0.05 to 1.0 RU/ml) (Fig. 1).

\section{PG triggers cell death in soybean cells.}

The viability of soybean cells treated with PG $(0.5 \mathrm{RU} / \mathrm{ml})$ was tested using the Evans blue method (Levine et al. 1996). The PG treatment was found to induce a twofold increase in the percentage of dead cells after $1 \mathrm{~h}$ of treatment $(22.8 \pm$ $0.4 \%)$ in comparison with untreated cells $(10.2 \pm 2.1 \%)$ (Fig. 2). Monitoring cell death over $12 \mathrm{~h}$ of PG treatment, we detected a progressive increase in the number of dead cells that reached nearly $100 \%$ after $12 \mathrm{~h}$ of PG incubation (Fig. 2).

Loss of cell viability was accompanied by changes in nuclear morphology, as examined by double staining of DNA with Hoechst 33342 (HO) and propidium iodide (PI) fluorescent dyes. In vivo, HO is a cell membrane-permeant dye that has access into slightly damaged as well as altered apoptotic

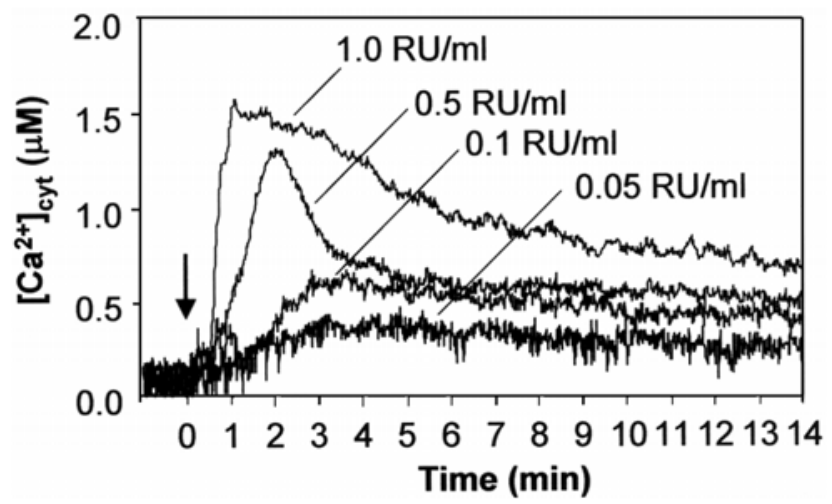

Fig. 1. Effect of endopolygalacturonase (PG) purified from Sclerotinia sclerotiorum on cytosolic $\mathrm{Ca}^{2+}$ concentration $\left(\left[\mathrm{Ca}^{2+}\right]_{\text {cyt }}\right)$ in soybean cells. At the time indicated (arrow) soybean cells stably expressing cytosolic aequorin were challenged with different doses of PG and the changes in $\left[\mathrm{Ca}^{2+}\right]_{\text {cyt }}$ were continuously recorded. These and the following traces are representative of three independent experiments, which gave very similar results.

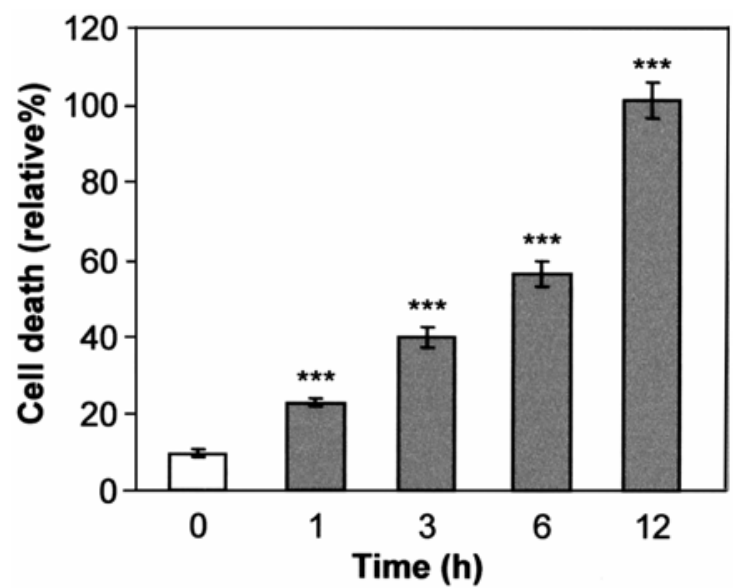

Fig. 2. Viability of soybean cells treated with endopolygalacturonase (PG). Exponentially growing cells were incubated with $\mathrm{PG}(0.5 \mathrm{RU} / \mathrm{ml})$ for different times (gray bars). Cells cultured without PG were taken as a control (white bar). The $100 \%$ value corresponds to cells treated for 10 min at $100^{\circ} \mathrm{C}$. Data are means \pm standard deviation of three independent experiments. Statistically significant at $P<0.005$ (three asterisks). nuclei, whereas PI is a cell-impermeant dye that can enter only in late apoptotic and necrotic cultured cells. These fluorochromes allow the discrimination of healthy $\left(\mathrm{HO}^{-} / \mathrm{PI}^{-}\right)$, apoptotic $\left(\mathrm{HO}^{+} / \mathrm{PI}^{-}\right)$, and necrotic $\left(\mathrm{HO}^{+} / \mathrm{PI}^{+}\right)$cells in an asynchronized cell population (Hamatake et al. 2000). After $1 \mathrm{~h}$ of PG treatment, about $15 \% \mathrm{HO}^{+} / \mathrm{PI}^{-}$nuclei (Fig. $3 \mathrm{E}$ and $\mathrm{F}$ ) and 20 to $30 \% \mathrm{HO}^{+} / \mathrm{PI}^{+}$nuclei (Fig. $3 \mathrm{H}$ and I) were observed, indicating chromatin condensation (HO positivity) and suggesting the simultaneous occurrence of both early and late apoptotic-like stages. In comparison, nuclei of untreated cells showed mainly the absence of $\mathrm{HO}$ and PI fluorescence, only about $5 \%$ of the cell population displayed positivity to both dyes (Fig. 3B and C).

Morphological observations under light microscopy revealed, in PG-treated cells, a gradual shrinkage of the nucleus and detachment of the plasma membrane from the cell wall as the cell death program proceeds (Fig. 3D and G). The detachment of the plasma membrane from the cell wall is considered one of the hallmarks indicating the occurrence of a PCD process in plant cells (Beers and McDowell 2001). Nuclei of control cells appeared larger and rounder compared with PG-treated cells, and the plasma membrane was completely adherent to the cell wall (Fig. 3A).

In order to investigate the mode of PG-induced cell death, all further analyses were carried out after $1 \mathrm{~h}$ of treatment. At this timepoint, in fact, the cell population is in a dynamic state toward PCD.

\section{PG-induced cell death is associated with} cytochrome $c$ release and caspase-like protease activation.

To clarify the mechanism of cell death induced by PG, attention was focused on the cytochrome c/caspase 9 PCD pathway and downstream targets such as caspase 3. Cytochrome $c$ release from mitochondria is an early event of apoptosis in animal cells. It is required for the activation of the caspase protease cascade as well as downstream events (Desagher and Martinou 2000). Cytosolic extracts from soybean cells were separated on sodium dodecyl sulfate-polyacrylamide gel electrophoresis (SDS-PAGE) and were analyzed by Western blot with an anti-cytochrome $c$ monoclonal antibody. In cytosolic
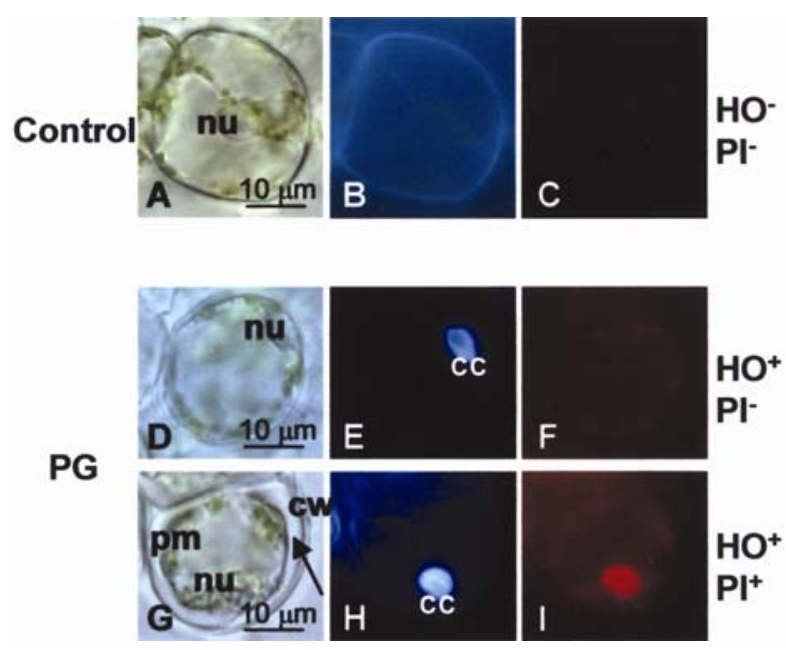

Fig. 3. Nucleus staining of endopolygalacturonase (PG)-treated cells. Untreated cells and cells treated for $1 \mathrm{~h}$ with $\mathrm{PG}(0.5 \mathrm{RU} / \mathrm{ml})$ were stained with Hoechst (HO) and propidium iodide (PI) and were processed for fluorescence microscopy. A through $\mathbf{C}$, untreated cells; D through I, cells treated with $0.5 \mathrm{RU} / \mathrm{ml} \mathrm{PG} ; \mathbf{E}$ and $\mathbf{F}$, early programmed cell death (PCD) nucleus; $\mathbf{H}$ and I, late PCD nucleus. Pictures represent typical examples. $\mathrm{cc}=$ chromatin condensation, $\mathrm{cw}=$ cell wall, $\mathrm{nu}=$ nucleus, and $\mathrm{pm}=$ plasma membrane. The arrow indicates the detachment of the plasma membrane from the cell wall. 
extracts from cells treated with PG $(0.5 \mathrm{RU} / \mathrm{ml})$ for $1 \mathrm{~h}$, the presence of cytochrome $c$ was detected; control cells did not show any cytochrome $c$ protein band (Fig. 4A). This result suggests the likely activation of a mitochondrial PCD pathway during PG treatment. To directly investigate whether PGinduced cell death is associated with the activation of caspaselike proteases, hydrolysis of the specific caspase 9 synthetic substrate LEHD and of the caspase 3 substrate DEVD, both conjugated with $p$-nitroaniline (pNA), was assayed in protein
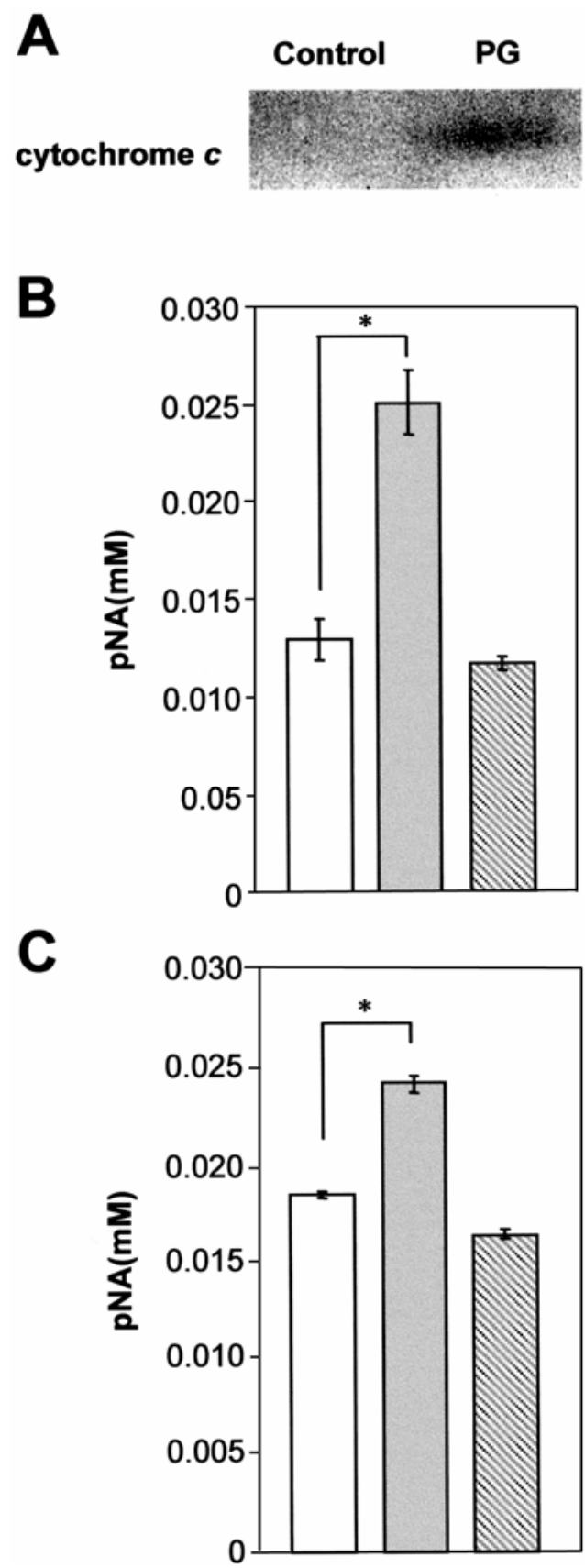

Fig. 4. Cytochrome $c$ release and measurements of caspase-like activities in soybean cells incubated with endopolygalacturonase (PG) $(0.5 \mathrm{RU} / \mathrm{ml})$ for $1 \mathrm{~h}$. A, Cytochrome $c$ accumulation in the cytosolic extracts from untreated (control) and PG-treated cells was assessed by Western blot analysis. B, Caspase 3-like activity in untreated cells (white bar), PGtreated cells (gray bar), and PG-treated cells in the presence of the caspase 3 inhibitor Ac-DEVD-CHO (3 $\mu \mathrm{M})$ (striped bar). C, Caspase 9-like activity in untreated cells (white bar), PG-treated cells (gray bar), and PGtreated cells in the presence of the caspase 9 inhibitor Ac-LEHD-CHO (3 $\mu \mathrm{M})$ (striped bar). Data are means \pm standard deviation of three independent experiments. Statistically significant at $P<0.05$ (one asterisk). extracts from soybean cells. Caspase 9-like activity in cells treated with $0.5 \mathrm{RU} / \mathrm{ml} \mathrm{PG}$ for $1 \mathrm{~h}$ was $1.86 \pm 0.12$ times greater than that in the control (Fig. 4B). Furthermore, incubation of cells with PG also heightened caspase 3-like activity by about $1.3 \pm 0.03$ times as compared with untreated cells (Fig. 4C). Although both analyzed caspase substrates were cleaved upon PG treatment, there was a quantitative difference between the two enzymatic reactions. The activity of caspase 9-like protease seemed to be about 1.4-fold higher than that of caspase 3-like protease (Fig. 4B and C). Both activities of caspase 9like and caspase 3-like proteases were significantly decreased by the Ac-LEHD-CHO and Ac-DEVD-CHO inhibitors of animal caspase 9 and 3, respectively (Fig. 4B and C). Thus, the mechanism of cell death induced by PG seems to involve cytochrome $c$ release, caspase 9-like and caspase 3-like activation, suggesting the occurrence of a PCD process.

PGIP blocks both the PG-induced $\mathrm{Ca}^{2+}$ signaling and PCD.

PGIP is constitutively present in the tissues of soybean seedlings (Favaron et al. 1994), and it is secreted in the culture medium by soybean cells (data not shown). However, the washing procedure carried out before the PG treatment freed the cell of any detectable PGIP activity. Therefore, exogenous PGIP (2 inhibitor units [IU] per milliliter) was administered to cell suspensions simultaneously with the PG treatment $(0.5 \mathrm{RU} / \mathrm{ml})$.

The simultaneous administration to cells of PG and its inhibitor PGIP resulted in the almost complete annulment of the PGinduced $\mathrm{Ca}^{2+}$ transient, with a remarkable reduction of phase 1 amplitude and the complete abolishment of the phase 2 plateau (Fig. 5A). It has to be noted that PGIP by itself could not elicit any significant $\left[\mathrm{Ca}^{2+}\right]_{c y t}$ elevation over the basal level. Indeed,
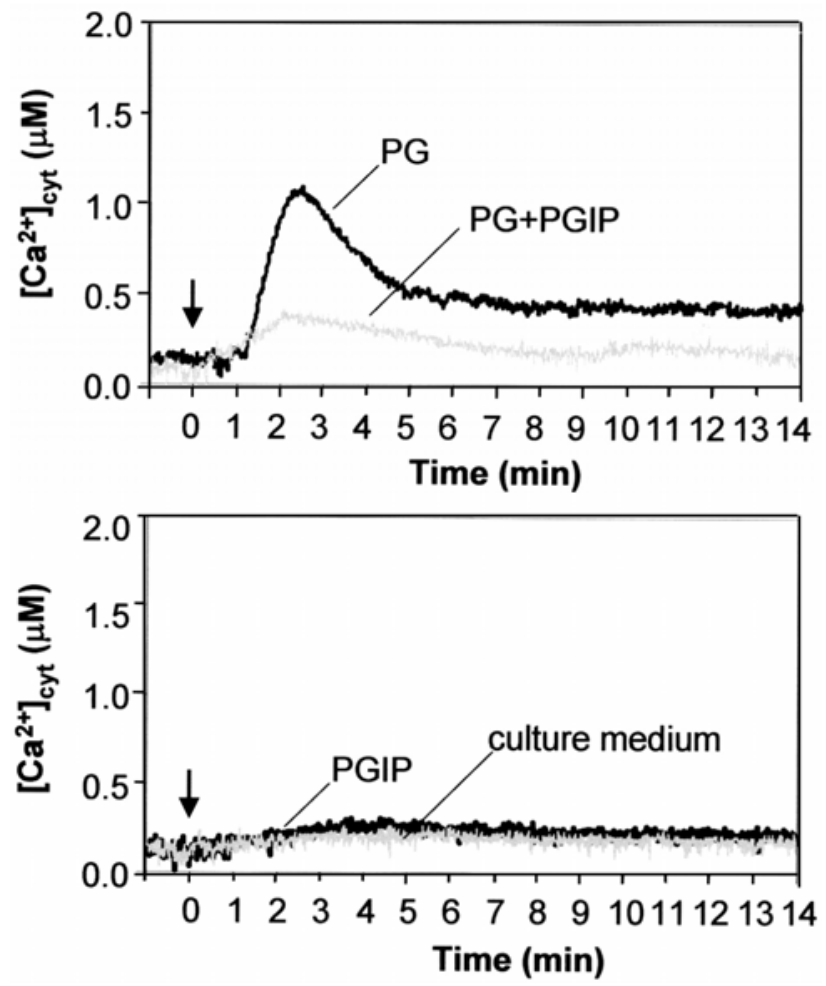

Fig. 5. Polygalacturonase inhibiting protein (PGIP) effectively blocks endopolygalacturonase (PG)-induced $\mathrm{Ca}^{2+}$ signaling. A, Cells were treated (arrow) with either PG $(0.5 \mathrm{RU} / \mathrm{ml})$ alone (black trace) or PG $(0.5 \mathrm{RU} / \mathrm{ml})$ and PGIP ( 2 inhibitor units per milliliter) administered simultaneously (gray trace) and their effect on cytosolic free- $\mathrm{Ca}^{2+}$ concentration $\left[\mathrm{Ca}^{2+}\right]_{\text {cyt }}$ was monitored. B, Cells were challenged (arrow) with PGIP (black trace) or culture medium containing the same percentage of the solvent as PGIPtreated cells (gray trace). 
the PGIP-induced $\mathrm{Ca}^{2+}$ trace appeared almost superimposable to that of control cells challenged with culture medium (Fig. 5B).

Figure 6 shows that PGIP effectively blocks the activation of the PG-induced PCD program, as demonstrated by the Evans blue cell viability assay (Fig. 6A) and double staining with $\mathrm{HO}$ and PI (Fig. 6B, panels e and f). Cell treatment with only PGIP did not induce either a decrease of cell viability (Fig. 6A) or positivity to $\mathrm{HO}$ and PI (Fig. 6B, panels $\mathrm{b}$ and $\mathrm{c}$ ).

\section{The cytosolic $\mathrm{Ca}^{2+}$ elevation is a key determinant of the PG-induced cell death.}

To investigate the role of $\mathrm{Ca}^{2+}$ in PG-activated signaling, the $\mathrm{Ca}^{2+}$ channel blocker $\mathrm{La}^{3+}$, which has been previously demonstrated to effectively abolish the $\mathrm{Ca}^{2+}$ transient elicited by OGs (Navazio et al. 2002), was applied to soybean cells $10 \mathrm{~min}$ before treatment with PG. The inhibitor markedly reduced both phase 1 and 2 of the $\mathrm{Ca}^{2+}$ transient (Fig. 7A). The annulment of the $\mathrm{Ca}^{2+}$ signal in $\mathrm{La}^{3+}$-pretreated cells abolished both caspase 3-like activation (Fig. 7B) and cell death (Fig. 7C), which did not significantly differ from that of control cells. Moreover, the number of HO/PI positive cells was comparable to the control (Fig. 7D), highlighting the absence of chromatin condensation in PG-treated cells after incubation with $\mathrm{La}^{3+}$.
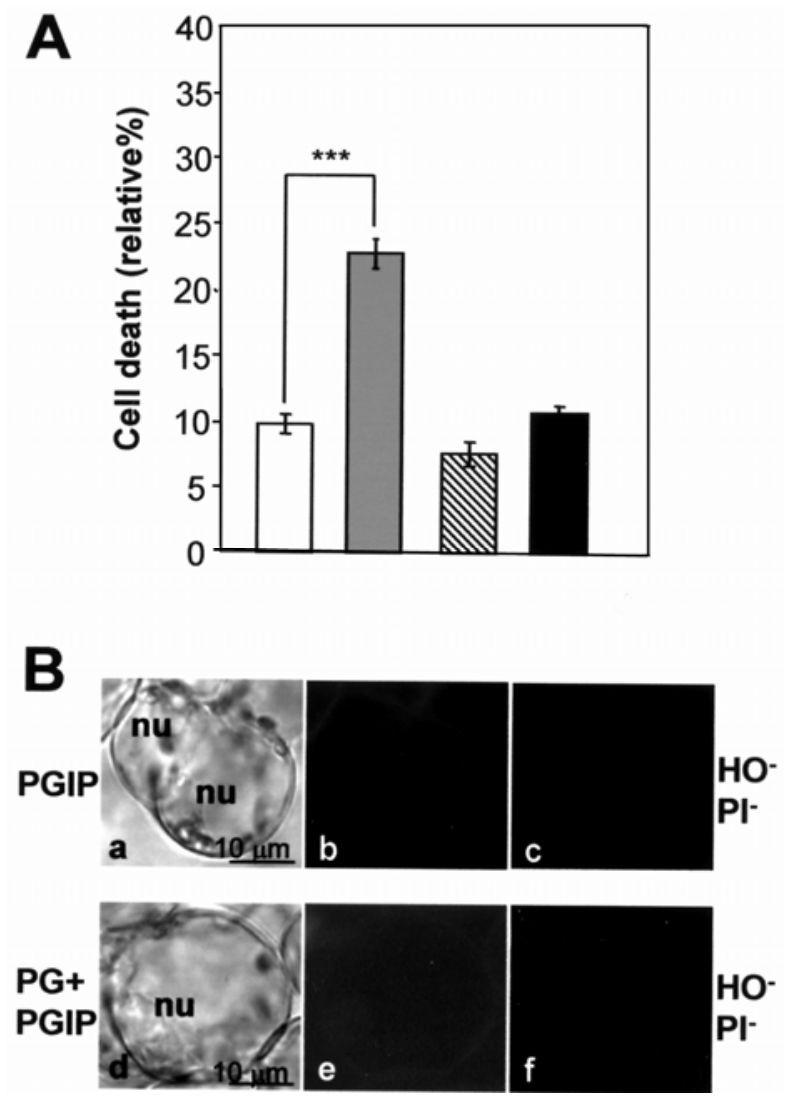

Fig. 6. Polygalacturonase inhibiting protein (PGIP) effectively blocks endopolygalacturonase (PG)-induced cell death. A, Exponentially growing cells were incubated for $1 \mathrm{~h}$ with PG $(0.5 \mathrm{RU} / \mathrm{ml})$ (gray bar), PGIP (2 inhibitor units [IU] per milliliter) (striped bar), or a mixture of PG $(0.5$ $\mathrm{RU} / \mathrm{ml}$ ) plus PGIP (2 IU/ml) (black bar). Cells cultured without PG and PGIP were taken as a control (white bar). Data are means \pm standard deviation of three independent experiments. Statistically significant at $P<$ 0.005 (three asterisks). B, Cells treated for $1 \mathrm{~h}$ with PGIP $(2 \mathrm{IU} / \mathrm{ml})$ and with PG $(0.5 \mathrm{RU} / \mathrm{ml})$ plus PGIP (2 IU/ml) were stained with Hoechst (HO) and propidium iodide (PI) dyes. a through c, PGIP-treated cells; $\mathbf{d}$ through f, PG plus PGIP-treated cells. Pictures represent typical examples. nu = nucleus.

\section{DISCUSSION}

In this paper, we show that administering to soybean cell cultures a PG produced by Sclerotinia sclerotiorum when infecting soybean plants triggers a rapid elevation in $\left[\mathrm{Ca}^{2+}\right]_{\text {cyt }}$, which is suggestive of $\mathrm{Ca}^{2+}$-mediated signaling induced by a secreted fungal enzyme. This enzyme in vivo degrades the pectic components of the plant cell wall, generating oligosaccharide fragments, which in turn, act as endogenous signaling molecules (Coté and Hahn 1994). The mixture of OGs deriving from PG enzymatic activity is known to activate a $\mathrm{Ca}^{2+}$ mediated signal pathway (Navazio et al. 2002). Nevertheless, the temporal kinetics of the OG-elicited $\mathrm{Ca}^{2+}$ transient significantly differs from that induced by treatment with PG. In particular, although both elicitors evoke a single immediate $\mathrm{Ca}^{2+}$ spike, the OG-activated $\mathrm{Ca}^{2+}$ transient is rapidly dissipated within a few minutes (Navazio et al. 2002), whereas the PGactivated $\mathrm{Ca}^{2+}$ signal persists for at least $1 \mathrm{~h}$, maintaining, in the cell, $\mathrm{Ca}^{2+}$ levels higher than the physiological ones. In both animal and plant cells, perturbations of $\mathrm{Ca}^{2+}$ homeostasis have been associated with cytotoxic events (Kass and Orrenius 1999; White and Broadley 2003).

Here, we provide evidence for the occurrence of PCD induced by PG in soybean cells. It must be noted that the products of PG enzymatic activity, namely OGs, do not by themselves induce cell death in either soybean cells (data not shown) or other experimental systems (Binet et al. 2001; Lecouriex et al. 2002; Shibuya and Minami 2001). Thus, PG seems to be, per se, the causative agent of the cell death, which could depend on the cell sensing of the protein as a virulence factor and may be unrelated to its enzymatic activity. Likewise, the elicitor activity of other fungal hydrolytic enzymes has been previously shown by various experimental approaches not to be necessarily due to the release of biologically active oligosaccharide fragments (Carden and Felle 2003; Martinez et al. 2001; Poinsott et al. 2003; Rouet-Mayer et al. 1997; Yano et al. 1998).

The elevation of cytosolic $\mathrm{Ca}^{2+}$ level seems to be essential for the induction of cell death. Indeed, the $\mathrm{Ca}^{2+}$ channel blocker $\mathrm{La}^{3+}$ abolishes both phases of the PG-induced $\mathrm{Ca}^{2+}$ transient, caspase 3-like activation, chromatin condensation, and cell death. A relationship between sustained $\left[\mathrm{Ca}^{2+}\right]_{\mathrm{cyt}}$ and activation of pathogen defense responses has been previously reported (Grant et al. 2000).

The sequence of events starting from signal perception to cell death in PG-treated cells has been partially unraveled in this paper. Based on previous findings by several authors (Boudart et al. 2003; Cotton et al. 2002; Poinsott et al. 2003), it can be argued that, downstream of the $\mathrm{Ca}^{2+}$ transient, an extracellular $\mathrm{H}_{2} \mathrm{O}_{2}$ accumulation can occur. Both $\left[\mathrm{Ca}^{2+}\right]_{\text {cyt }}$ elevation (Viroleinen et al. 2002) and production of reactive oxygen species (Tiwari et al. 2002) may be cocausative agents in triggering PCD through the mediation of mitochondria. Our data provide evidence for the release, in the cytoplasm, of cytochrome $c$ as well as activation of caspase-like proteases in PG-induced cell death. Nevertheless, the involvement of other proteases, such as the newly characterized serin proteases named saspases (Coffeen and Wolpert 2004), cannot be ruled out.

The complete block of both PG-induced $\mathrm{Ca}^{2+}$ transient and PCD following the interaction of PG with its inhibitor PGIP is consistent with an interference of PGIP with signaling by PG. PGIP, by complexing PG, besides blocking the substrate admittance to the enzyme-active site (Di Matteo et al. 2003), might prevent the ligand access to the putative receptor, hampering its recognition. Consequently, any cellular receptor-mediated response to the elicitor is annulled. The inhibition of $\mathrm{H}_{2} \mathrm{O}_{2}$ production shown by Poinsott and associates (2003), consequent 
to the simultaneous administration of PG and PGIP to grapevine cells, gives support to this hypothesis. An open question remains whether the PGIP role in the modulation of PG functioning is really dual (i.e., block of PG recognition and of its enzymatic activity) or if, rather, all PG-induced cell responses are prevented by the failed PG interaction with its receptor. Poinsott and associates (2003) speculated that the PG catalytic domain and the recognition motif might correspond. Others have also suggested (De Lorenzo et al. 1997; Esquerré-Tugayé 2000; James and Dubery 2001) that PGIP might act as a cellsurface receptor or, at least, be part of a receptor complex.

In conclusion, a PG produced early during plant infection by S. sclerotiorum is a candidate factor for triggering pathogeninduced PCD. As recently reported, this necrotrophic fungus seems to co-opt PCD response in host cells to produce disease symptoms (Dickman et al. 2001; Govrin and Levine 2000), and the expression of animal antiapoptotic genes in transgenic tobacco plants prevents fungal colonization and disease development (Dickman et al. 2001).

The plant PGIP blocking the PCD induced by this $S$. sclerotiorum $\mathrm{PG}$ may be a successful instrument to improve plant resistance to this pathogen.

\section{MATERIALS AND METHODS}

Plant material.

Soybean (Glycine max L.) suspension cell cultures stably expressing cytosolic aequorin (Mithöfer et al. 1999) were provided by G. Neuhaus (Freiburg, Germany). Cells were cultivated in Murashige and Skoog liquid medium supplemented with $0.5 \%$ sucrose, $10 \mu \mathrm{g}$ naphthaleneacetic acid per milliliter, $2 \mu \mathrm{g}$ of kinetin per milliliter, $1 \mu \mathrm{g}$ of thiamine- $\mathrm{HCl}$ per milliliter, and $10 \mu \mathrm{g}$ of kanamycin per milliliter on a rotary shaker $(80 \mathrm{rpm})$ at $24^{\circ} \mathrm{C}$ under a 16 -h photoperiod and were subcultured every three weeks with a $10 \%$ (vol/vol) inoculum.

\section{Fungus and plant infection.}

The B-24 isolate of S. sclerotiorum (Lib. De Bary) was grown on potato dextrose agar medium to obtain mycelium for soybean inoculation. Six-day-old etiolated soybean plants were obtained at $25^{\circ} \mathrm{C}$ in sterilized moist vermiculite. Soybean seedlings were inoculated by placing plugs $(10 \times 2 \mathrm{~mm})$ of mycelium-colonized agar, cut from marginal zones of colonies, along the middle region of hypocotyls. The trays
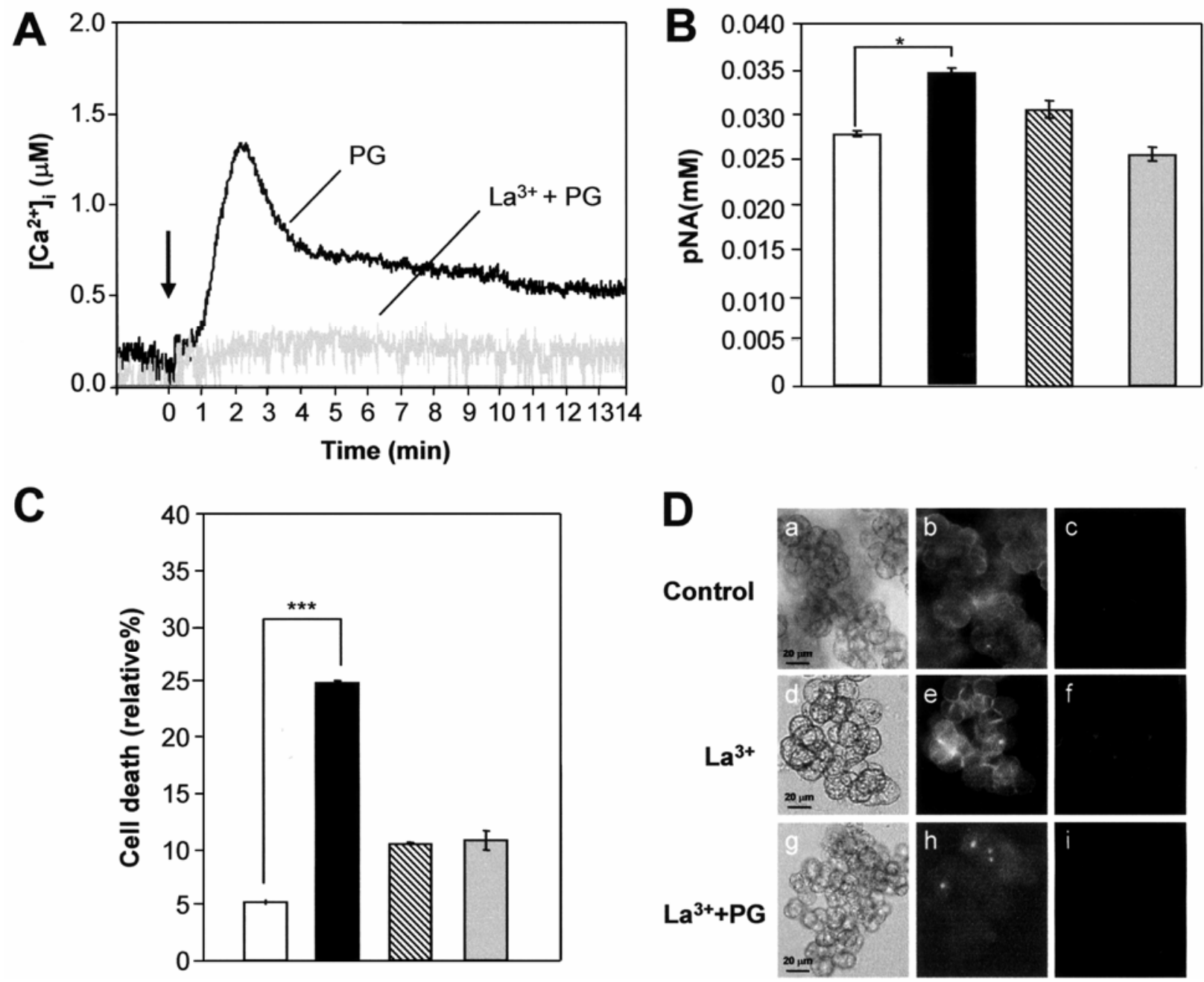

Fig. 7. $\mathrm{La}^{3+}$ inhibition of endopolygalacturonase (PG)-triggered cytosolic $\mathrm{Ca}^{2+}$ concentration $\left[\mathrm{Ca}^{2+}\right]_{\text {cyt }}$ elevations, caspase $3-$ like activity, chromatin condensation, and cell death. A, Cells were incubated with $3 \mathrm{mM} \mathrm{La}^{3+}$ (gray trace) for $10 \mathrm{~min}$ prior to the addition of PG ( $0.5 \mathrm{RU} / \mathrm{ml}$ ) (arrow), and the Ca ${ }^{2+}$ response was monitored. Control cells were treated only with PG (black trace). B, Caspase 3-like activity and $\mathbf{C}$, viability of soybean cells treated for $1 \mathrm{~h}$ with PG $(0.5 \mathrm{RU} / \mathrm{ml})$ alone (black bar) or $3 \mathrm{mM} \mathrm{La}^{3+}$ (striped bar) or La ${ }^{3+}$ plus PG (gray bar). Cells cultured without PG and La ${ }^{3+}$ were taken as a control (white bar). Data are means \pm standard deviation of three independent experiments. Statistically significant at $P<0.05$ (one asterisk) and $P<0.005$ (three asterisks). D, Cells treated for $1 \mathrm{~h}$ with PG $(0.5 \mathrm{RU} / \mathrm{ml})$ after a 10 -min pretreatment with $3 \mathrm{mM} \mathrm{La}^{3+}$ were stained with Hoechst and propidium iodide dyes. a through c, Control cells; $\mathbf{d}$ through $\mathbf{f}$, cells treated with $\mathrm{La}^{3+} ; \mathbf{g}$ through $\mathbf{i}$, cells treated with La ${ }^{3+}$ plus PG. Pictures represent typical examples. Cells cultured without PG and $\mathrm{La}^{3+}$ were taken as a control. 
containing inoculated seedlings were sealed with plastic film and were incubated at $25^{\circ} \mathrm{C}$ in the dark. Infected tissue was harvested for PG extraction and purification $48 \mathrm{~h}$ after inoculation.

\section{PG extraction, purification and assay.}

A basic PG isoform of $S$. sclerotiorum was extracted and purified from infected soybean tissue as reported (Favaron et al. 1997). Briefly, the PG was purified by two successive preparative isoelectrofocusing (IEF) runs in the range of $\mathrm{pH}$ 3 to 10 and 6 to 9, respectively, and by a MonoS cation-exchange column. PG activity was determined as an increase in reducing end groups over time. Reducing end groups were measured using the method described by Milner and Avigad (1967), with D-galacturonic acid as a standard. The incubation mixture contained $200 \mu \mathrm{l}$ of $0.5 \%$ polygalacturonic acid (PGA, from orange, code P3889, lot 85C-0121; Sigma-Aldrich, St. Louis) in $100 \mathrm{mM}$ sodium acetate buffered at $\mathrm{pH}$ 4.6 and $0.1 \mathrm{mg}$ of bovine serum albumin per milliliter. One RU was defined as that producing $1 \mu \mathrm{mol}$ of reducing end groups per minute at $30^{\circ} \mathrm{C}$ and corresponds to about $1.4 \mu \mathrm{g}$ of PG protein.

\section{PGIP production and assay.}

PGIP was obtained from leaves of 14-day-old plants of Phaseolus vulgaris L. (cv. Borlotto). Proteins were extracted and PGIP was purified by preparative IEF (pH 3 to 10), PGSepharose affinity chromatography, and MonoS cation-exchange chromatography as previously reported (Favaron et al. 1994). PGIP activity was determined against the purified PG of $S$. sclerotiorum, by adding the inhibitor to the enzyme mixture described in the PG-reducing end groups assay. One IU was defined as that required to reduce by $50 \%$ the activity of one PG unit. About 4 IU (approximately $3.2 \mu \mathrm{g}$ of PGIP) were used in order to abolish completely $1 \mathrm{PG}$ unit.

\section{PG treatment.}

Cell treatments with the $S$. sclerotiorum PG were performed three weeks after reinoculation, during the exponential growth phase of the cells. Cells were washed three times with 10 vol of fresh hormone-free culture medium and were used after 30 min of equilibration. Control cells were incubated in the same conditions without the elicitor.

\section{Aequorin-dependent $\mathrm{Ca}^{2+}$ measurements.}

Reconstitution of the $\mathrm{Ca}^{2+}$-sensitive photoprotein aequorin was carried out by incubating soybean cells with $5 \mu \mathrm{M}$ coelenterazine overnight, in the dark. All measurements were performed at room temperature in a final volume of $50 \mu \mathrm{l}$, containing approximately $5 \mathrm{mg}$ (fresh weight) of reconstituted cell-suspension culture. Treatment with PG was carried out by injecting, with a light-tight syringe through the luminometer port, an equal volume of twofold-concentrated stock solutions (dissolved in the basal cell culture medium) into the cell suspension culture. All experiments were terminated by discharging the remaining aequorin pool with $0.33 \mathrm{M}$ $\mathrm{CaCl}_{2}$ in $10 \%$ ethanol. Luminescence data were collected and elaborated into $\left[\mathrm{Ca}^{2+}\right]$ values by a computer algorithm based on the $\mathrm{Ca}^{2+}$ response curve of aequorin (Brini et al. 1995).

\section{Cell viability and treatments.}

Cell viability was determined by incubation with $0.05 \%$ Evans blue (Levine et al. 1996). Cells were then extensively washed with deionized water to remove excess and unbound dye. Dye bound to dead cells was solubilized in methanol/SDS (50:1) for $30 \mathrm{~min}$ at $50^{\circ} \mathrm{C}$ and was quantified by absorbance at $600 \mathrm{~nm}$.

\section{Nucleus staining.}

To analyze nuclear morphological changes, cells were stained with fluorescence dyes $\mathrm{HO}$ and PI. Suspension cells (3-week-old) were incubated in darkness with $8 \mu \mathrm{g}$ of $\mathrm{HO}$ per milliliter (Sigma-Aldrich) and $5 \mu \mathrm{g}$ of PI per milliliter (SigmaAldrich) at room temperature for $10 \mathrm{~min}$ and were observed under fluorescence microscopy, by using an excitation light of $350 \mathrm{~nm}$ and $570 \mathrm{~nm}$, respectively, for the two dyes.

\section{Detection of cytochrome $c$ release.}

Cytosolic protein extracts were obtained by incubating cells $\left(15 \mathrm{~min}\right.$ at $\left.4^{\circ} \mathrm{C}\right)$ with $75 \mathrm{mM} \mathrm{NaCl}, 1 \mathrm{mM} \mathrm{NaH} \mathrm{PO}_{4}, 8 \mathrm{mM}$ $\mathrm{Na}_{2} \mathrm{HPO}_{4}, 250 \mathrm{mM}$ sucrose, and digitonin $(380 \mu \mathrm{g} / \mathrm{ml})$. Cytosolic fractions were then separated by centrifugation $(5 \mathrm{~min}$, $\left.14,000 \mathrm{rpm}, 4^{\circ} \mathrm{C}\right)$, were loaded $(10 \mu \mathrm{g})$ on SDS-PAGE $(12 \%$ acrylamide gel) (Laemmli 1970), and were transferred to Immobilon-P transfer membrane (Millipore, Bedford, MA, U.S.A.) for chemiluminescent detection according to Towbin and associates (1979). Filters were incubated with 5\% skim milk in Tris-buffered saline (TBS) for $1 \mathrm{~h}$ and were probed with a mouse monoclonal cytochrome $c$ antibody $(4 \mu \mathrm{g} / \mathrm{ml})$ (BioSource International, Camarillo, CA, U.S.A.) for 2 h. After incubation, filters were washed two times with a $0.05 \%$ Tween/ TBS solution, followed by one wash in TBS before incubation with the secondary antibody. Labeled proteins were detected using CDP-star (Biolabs, Hitchin, U.K.) and autoradiography films (Sigma-Aldrich).

\section{Measurements of caspase-like activities.}

Caspase 9- and caspase 3-like activities were measured using the Caspase- 9 and Caspase- 3 colorimentric activity assay kits (Chemicon International, Inc., Temecula, CA, U.S.A.), respectively, as described by the manufacturer. The assays are based on spectrophotometric detection of the chromophore pNA after the caspase-dependent cleavage from the labeled substrates DEVDpNA or LEHD-pNA by active caspase 3 or 9, respectively. Cytosolic protein extracts from soybean cells $(15 \mu \mathrm{g})$ were incubated for $2 \mathrm{~h}$ at $37^{\circ} \mathrm{C}$ with DEVD-pNA or LEHD-pNA, in the presence or absence of $3 \mu \mathrm{M}$ caspase inhibitors Ac-DEVD-CHO (for caspase 3) or Ac-LEHD-CHO (for caspase 9). Caspase-like activity was determined by spectrophotometric quantification of the free $\mathrm{pNA}(\lambda \mathrm{em}=405 \mathrm{~nm})$.

\section{Statistical analysis.}

Data are presented as mean plus or minus standard deviation of three independent experiments, and the differences between groups were assessed by Student's $t$-test.

\section{ACKNOWLEDGMENTS}

We thank G. Neuhaus (Freiburg, Germany) for kindly providing the transgenic soybean cells expressing cytosolic aequorin. This work was supported by grants from Progetti di Ricerca di Interesse Nazionale 2001 (prot. 2001055885) and Fondo per gli Investimenti della Ricerca di Base 2002 (prot. RBNE01K2E7).

\section{LITERATURE CITED}

Beers, E. P., and McDowell, J. M. 2001. Regulation and execution of programmed cell death in response to pathogens, stress and developmental cues. Curr. Opin. Plant Biol. 4:561-567.

Binet, M.-N., Humbert, C., Lecouriex, D., Vantard, M., and Pugin, A. 2001. Disruption of microtubular cytoskeleton induced by cryptogein, an elicitor of hypersensitive response in tobacco cells. Plant Physiol. 125:564-572.

Boudart, G., Charpentier, M., Lafitte, C., Martinez, Y., Jauneau, A., Gaulin, E., Esquerré-Tugayé M.-T., and Dumas, B. 2003. Elicitor activity of a fungal polygalacturonase in tobacco requires a functional catalytic site and cell wall localization. Plant Physiol. 131:93-101. 
Brini, M., Marsault, R., Bastianutto, C., Alvarez, J., Pozzan, T., and Rizzuto, R. 1995. Transfected aequorin in the measurements of cytosolic $\mathrm{Ca}^{2+}$ concentration $\left(\left[\mathrm{Ca}^{2+}\right]_{\mathrm{c}}\right)$. J. Biol. Chem. 270:9896-9903.

Carden, D. E., and Felle, H. H. 2003. The mode of action of cell-wall degrading enzymes and their interference with Nod factor signaling in Medicago sativa root hairs. Planta 216:993-1002.

Coffeen, W. C., and Wolpert, T. J. 2004. Purification and characterization of serin proteases that exhibit caspase-like activity and are associated with programmed cell death in Avena sativa. Plant Cell 16:857-873.

Cotton, P., Rascle, C., and Fevre, M. 2002. Characterization of PG2, an early endoPG produced by Sclerotinia sclerotiorum, expressed in yeast. FEMS (Fed. Eur. Microbiol. Soc.) Microbiol. Lett. 213:239-244.

Coté, F., and Hahn, M. G. 1994. Oligosaccharins: Structures and signal transduction. Plant Mol. Biol. 26:1379-1411.

De Lorenzo, G., and Ferrari, S. 2002. Polygalacturonase-inhibiting proteins in defense against phytopathogenic fungi. Curr. Opin. Plant Biol. 5:1-5.

De Lorenzo, G., Castoria, R., Bellincampi, D., and Cervone, F. 1997. Fungal invasion enzymes and their inhibition. Pages 61-83 in: The Mycota V Part A. Plant Relationships. G. C. Carrol and P. Tudzynski, eds. Springer-Verlag, Berlin.

De Lorenzo, G., D'Ovidio R., and Cervone, F. 2001. The role of polygalacturonase-inhibiting proteins (PGIPs) in defense against pathogenic fungi. Annu. Rev. Phytopathol. 39:313-325.

Desagher, S., and Martinou J. C. 2000. Mitochondria as the central control point of apoptosis. Trends Cell Biol. 10:369-377.

Di Matteo, A., Federici, A., Mattei, B., Salvi, G., Johnson, K. A., De Lorenzo, G., Tsernoglou, D., and Cervone, F. 2003. The crystal structure of polygalacturonase-inhibiting protein (PGIP), a leucin-rich repeat protein involved in plant defense. Proc. Natl. Acad. Sci. U.S.A. 100:10124-10128.

Dickman, M. B., Park, Y. K, Oltersdorf, T., Li, W., Clemente, T. and French, R. 2001. Abrogation of disease development in plants expressing animal antiapoptotic genes. Proc. Natl. Acad. Sci. U.S.A. 98:6957-6962.

Esquerré-Tugayé, M.-T., Boudart, G., and Dumas, B. 2000. Cell wall degrading enzymes, inhibitory proteins, and oligosacchairdes participate in the molecular dialogue between plants and pathogens. Plant Physiol. Biochem. 38:157-163.

Favaron, F., and Marciano, P. 1992. Polygalacturonase regulation in Sclerotinia sclerotiorum: Effect of carbon source on the isoenzymatic pattern. Riv. Patol. Veg. S. V. 2:111-123.

Favaron, F., D’Ovidio, R., Porceddu, E., and Alghisi, P. 1994. Purification and molecular characterization of a soybean polygalacturonase-inhibiting protein. Planta 195:80-87.

Favaron, F., Castiglioni, C., D’Ovidio, R., and Alghisi, P. 1997. Polygalacturonase inhibiting proteins from Allium porrum L. and their role in plant tissue against fungal endo-polygalacturonases. Physiol. Mol. Plant Pathol. 50:403-417.

Favaron, F., Sella, L., and D’Ovidio, R. 2004. Relationships among endopolygalacturonase, oxalate, $\mathrm{pH}$, and plant polygalacturonase-inhibiting protein (PGIP) in the interaction between Sclerotinia sclerotiorum and soybean. Mol. Plant-Microbe Interact. 17:1402-1409.

Godoy, G., Steadman, J. R., Dickman, M. B., and Dam, R. 1990. Use of mutants to demonstrate the role of oxalic acid in pathogenicity of Sclerotinia sclerotiorum on Phaseolus vulgaris. Physiol. Mol. Plant Pathol. 37:179-191.

Govrin, E. M., and Levine, A. 2000. The hypersensitive response facilitates plant infection by the necrotrophic pathogen Botrytis cinerea. Curr. Biol. 10:751-757.

Grant, M., Brown, I., Adams, S., Knight, M., Ainslie, A., and Mansfield, J. 2000. The RPM1 plant disease resistance gene facilitates a rapid and sustained increase in cytosolic calcium that is necessary for the oxidative burst and hypersensitive cell death. Plant J. 23:441-450.

Hamatake, M., Iguchi, K., Hirano, K., and Ishida, R. 2000. Zinc induces mixed types of cell death, necrosis, and apoptosis in molt-4 cells. J Biochem. 128:933-939.
James, J. T., and Dubery, I. A. 2001. Inhibition of polygalacturonase from Verticillium daliae by a polygalacturonase inhibiting protein from cotton. Phytochemistry 57:149-156.

Kass, G. E. N., and Orrenius, S. 1999. Calcium signaling and cytotossicity. Environ. Health Perspect. 107:25-35.

Laemmli, U. K. 1970. Cleavage of structural proteins during the assembly of the head of bacteriophage T4. Nature 227:680-685.

Lecourieux, D., Mazars, C., Pauly, N., Ranjeva, R., and Pugin, A. 2002. Analysis and effects of cytosolic free calcium increases in response to elicitors in Nicotiana plumbaginifolia cells. Plant Cell 14:2627-2641.

Levine, A., Pennell, R. I., Alvarez, M. E., Palmer, R. and Lamb, C. 1996. Calcium-mediated apoptosis in a plant hypersensitive disease resistance response. Curr. Biol. 6:427-437.

Marciano, P., Di Lenna, P. and Magro, P. 1983. Oxalic acid, cell walldegrading enzymes and $\mathrm{pH}$ in pathogenesis and their significance in the virulence of two Sclerotinia sclerotiorum isolates on sunflower. Physiol. Plant Pathol. 22:339-345.

Martinez, C., Blanc, F., Le Claire, E., Besnard, O., Nicole, M., and Bacou, J.-C. 2001. Salycilic acid and ethylene pathways are differentially activated in melon cotyledons by active or heat-denaturated cellulase from Trichoderma longibrachiatum. Plant Physiol. 127:334-344.

Milner, Y., and Avigad, G. 1967. A copper reagent for the determination of hexuronic acids and certain ketohexoses. Carbohydr. Res. 4:359-361.

Mithöfer, A., Ebel, J., Bhagwat, A. A., Boller, T., and Neuhaus-Url, G. 1999. Transgenic aequorin monitors cytosolic calcium transients in soybean cells challenged with $\beta$-glucan or chitin elicitors. Planta 207:566574.

Navazio, L., Moscatiello, R., Bellincampi, D., Baldan, B., Meggio F., Brini, M., Bowler, C., and Mariani, P. 2002. The role of calcium in oligogalacturonide-activated signaling in soybean cells. Planta 215:596605.

Poinsott, B., Vandelle, E., Bentéjac, M:, Adrian, M., Levis, C., Brygoo, Y., Garin, J., Sicilia, F., Coutos-Thévenot, P., and Pugin, A. 2003. The endopolygalcturonase 1 from Botrytis cinerea activates grapevine defense reactions unrelated to its enzymatic activity. Mol. Plant-Microbe Interact. 16:553-564.

Prade, R. A., Zhan, D., Ayoubi, P., and Mort, A. J. 1999. Pectins, pectinases and plant-microbe interactions. Biotech. Genet. Eng. Rev. 16:361-391.

Ridley, B. L., O’Neill, M. A., and Mohnen, D. 2001. Pectins: Structure, biosynthesis and oligogalcturonide-related signaling. Phytochemistry 57:929-967.

Rouet-Mayer, M.-A, Mathieu, Y., Cazalé, A.-C., Guern, J., and Laurière C. 1997. Extracellular alkalinization and oxidative burst induced by fungal pectin lyase in tobacco cells are not due to the perception of oligogalacturonide fragments. Plant Physiol. Biochem. 35:321-330.

Shibuya, N., and Minami, E. 2001. Oligosaccharide signaling for defence responses in plant. Physiol. Mol. Plant Pathol. 59:223-233.

Tiwari, B. S., Belenghi, B., and Levine, A. 2002. Oxidative stress increased respiration and generation of reactive oxygen species, resulting in ATP depletion, opening of mitochondrial permeability transition, and programmed cell death. Plant Physiol. 128:1271-1281.

Towbin, H., Staehelin, T., and Gordon, J. 1979. Electrophoretic transfer of proteins from polyacrylamide gels to nitrocellulose sheets: Procedure and some applications. Proc. Natl. Acad. Sci. U.S.A. 76:4350-4354.

Virolainen, E., Blokhina, O., and Fagerstedt, K. 2002. $\mathrm{Ca}^{2+}$-induced high amplitude swelling and cytochrome $c$ release from wheat (Triticum aestivum L.) mitochondria under anoxis stress. Ann. Bot. 90:509-516.

White, P. J., and Broadley, M. R. 2003. Calcium in plants. Ann. Bot. 92:487- 511

Willats, W. G. T., McCartney, L., Mackie, W., and Knox, J. P. 2001. Pectins: Cell biology and prospects for functional analysis. Plant Mol. Biol. 47:9-27.

Yano, A., Suzuki, K., Uchimiya, H., and Shinshi, H. 1998. Induction of hypersensitive cell death by a fungal protein in cultures of tobacco cells. Mol. Plant-Microbe Interact. 11:115-123. 